\title{
Produkcja broni w czasie okupacji
}

\section{Weapons manufacturing in the occupation}

\section{Streszczenie}

W artykule przedstawiono przykłady zastosowania spawania łukowego i acetyleno-tlenowego przez ruch oporu podczas II wojny światowej. Omówiono broń ręczną i pojazdy bojowe wykonane w latach 1939 - 1944 na terenie Generalnej Guberni.

\section{Abstract}

The article presents examples of the use of arc welding and air-acetylene welding by the resistance movement in the World War II. Presented handguns as well as fighting vehicles made between 1939-1944 in the General Government.

\section{Wstęp}

Wybuch II wojny światowej spowodował wstrzymanie produkcji przemysłowej. Z czasem jednak zaczęły powstawać warsztaty rzemieślnicze, a Niemcy otwierali fabryki, wykorzystując istniejące zasoby. W artykule skoncentrowano się na wykorzystaniu spawania przez ruch oporu na terenie Generalnej Guberni (GG) z pominięciem produkcji spawalniczej w zakładach niemieckich.

Broń, niezbędna dla ruchu oporu, była bardzo trudno dostępna. W związku z tym na terenie GG rozpoczęto konspiracyjną produkcję granatów, granatników i broni maszynowej. Podczas okupacji powstał również wóz bojowy „Kubuś” oraz miotacz butelek zapalających „Kusza”. We wszystkich przypadkach do wytwarzania broni stosowano technologie spawalnicze. Spawanie było również wykorzystywane do naprawy uzbrojenia.

\section{Broń ręczna}

Pierwszym rodzajem broni, którego produkcję podjęto w okupowanym kraju, były granaty (rys. 1). Pierwsze granaty, o nazwie „Filipinka” opuściły konspiracyjną wytwórnię w Warszawie już w 1940 r. [1].

Granaty wykonywano z rur wodociągowych, które cięto na tokarkach, następnie do powstałych tulei spawano denka i dokręcano pokrywki z otworami na zapalnik. Już pierwszego dnia wyprodukowano

Dr inż. Anna Pocica - Politechnika Opolska.

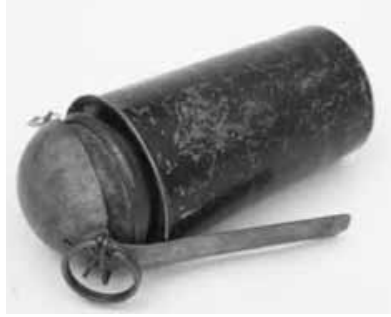

Rys. 1. Granat ręczny „Filipinka” [18]

Fig. 1. „Filipinka” hand grenade [18]

233 granaty [1], a do końca 1944 r., wg jednych źródeł 115 tys. [13], a według innych ok. 240 tys. sztuk [18]. Z powodu ostrzelania warsztatu mieszczącego się na Świętojerskiej, trzeba było przenieść produkcję na Nowomiejską, gdzie nie było maszyn do spawania. Prace mechaniczne wykonywano ręcznie, a spawanie w warsztacie na Długiej.

Jednym z największych warsztatów był zakład mieszczący się w budynku Związków Spółdzielni Mleczarskich i Jajczarskich na Hożej 1, pracujący dla konspiracji już od 1942 r., w którym w czasie powstania, oprócz granatów, produkowano butelki zapalające, granatniki, a także naprawiano broń. Spawano prądem elektrycznym (łukiem) lub palnikiem acetylenowo-tlenowym [1].

W granatnikach spawano dno komory wybuchowej i uchwyty ułatwiające jej odkręcenie (rys. 2) [2]. Dno było przyspawane elektrycznie, wykonywano więc spoiny pachwinowe i obwodowe [3]. Łącznie wyprodukowano ok. 25 granatników [4].

Spawanie stosowano również przy produkcji naboi do granatników. Granat był wykonany z rury o grubości ścianki $3 \mathrm{~mm}, \mathrm{z}$ jednej strony zakrytej przyspawanym dnem, z drugiej dokręcaną pokrywką [4]. Granaty, od 1944 r., produkowano również w Poznaniu w wytwórni Focke Wulf. Dno do tulei żeliwnych spawano 


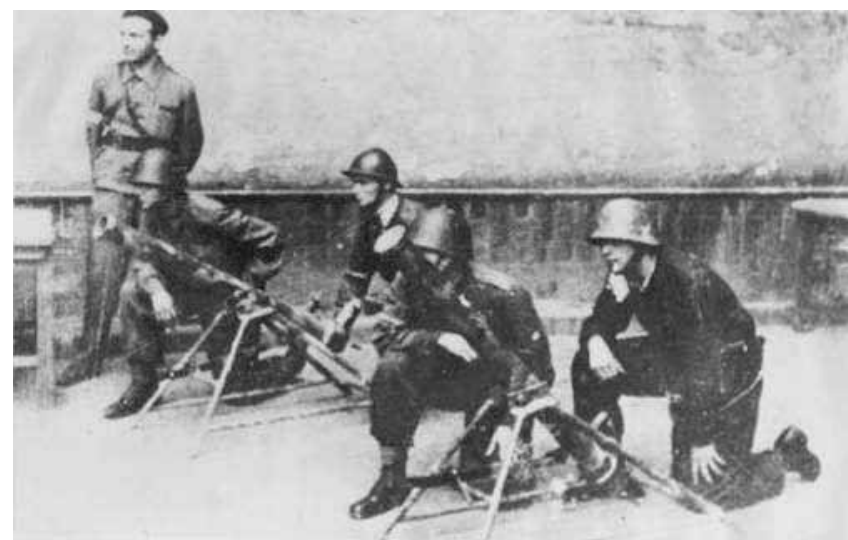

Rys. 2. Powstańcze granatniki [19]

Fig. 2. Insurgent grenade launchers [19]

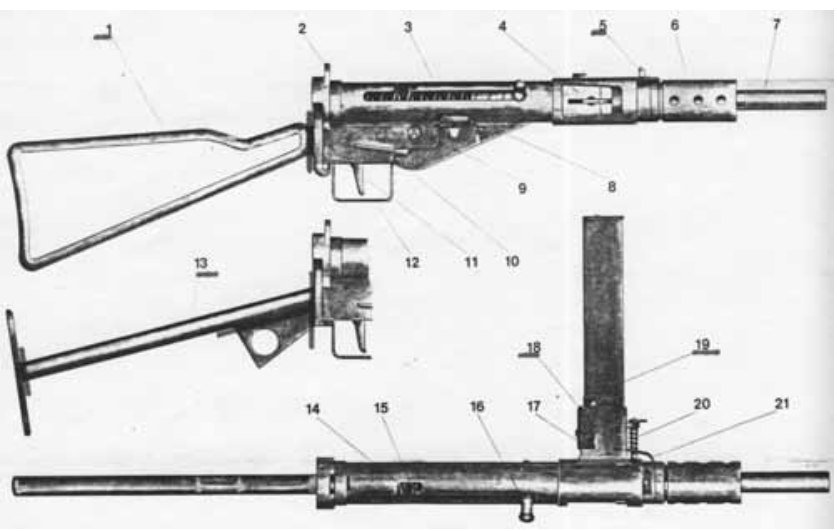

Rys. 3. Pistolet maszynowy Sten z zaznaczonymi spoinami Fig. 3. Sten submachine gun with the indicated joints

samodzielnie wykonaną spawarką elektryczną [5]. W Ostrowcu produkcje granatów prowadzono w kilku miejscach, jednak głównym były Zakłady Ostrowieckie. Powołano tam specjalną grupę techniczną, która opracowała pierwszą dokumentację. W Zakładach, na wydziale montowni, wykonywano tuleje o średnicy $50 \mathrm{~mm}$ i dna granatów. Części te wywożono do pałacu Wielopolskich w Częstocicach, gdzie w piwnicy spawano granaty. Aparat spawalniczy i 100 metrów kabla pochodziły z Zakładów Ostrowieckich, a jeden z najlepszych spawaczy, Edward Czuba, został oddelegowany do montowni. Ponieważ zapotrzebowanie oddziałów partyzanckich i grup dywersyjnych było coraz większe, rozpoczęto również spawanie granatów w warsztacie Mirosława Krakowiaka ps. Krakus - pracownika wydziału montowni, i w prywatnym warsztacie Stanisława Białasa [6]. W warsztacie Białasa odbywał się też montaż pistoletów maszynowych wg wzoru pistoletu Sten. Produkcję tych pistoletów rozpoczęto pod koniec 1943 r. w narzędziowni Zakładów Ostrowieckich z części dostarczonych z Radomia i Skarżyska. Steny produkowano również $w$ warsztatach firmy „Dom Handlowy” Sypniewskiego i Jakubowskiego w Krakowie, wybudowanych w latach 1941-1942. Można przyjąć, że prototypowe egzemplarze pistoletów zbudowano na przełomie grudnia 1942 i stycznia 1943 r., a produkcję rozwinięto w pierwszej połowie 1943 r. [7].

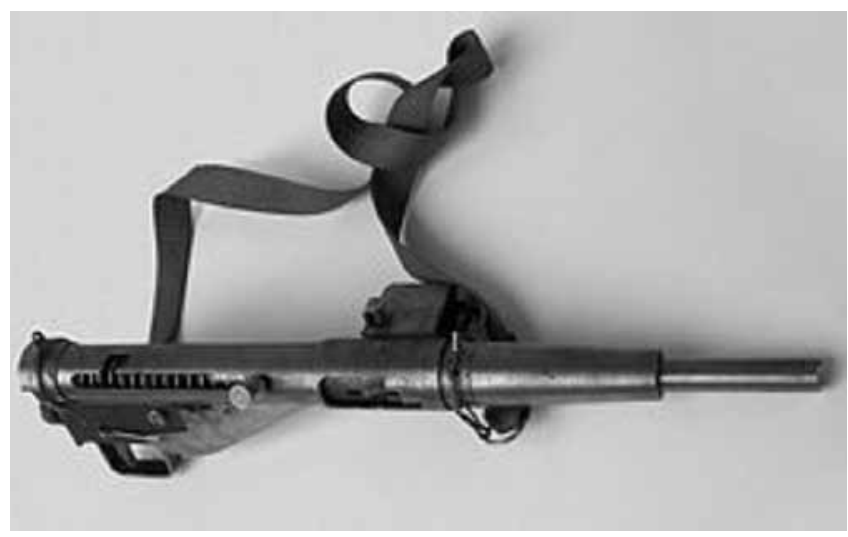

Rys. 4. Replika pistoletu KIS [20]

Fig. 4. KIS gun replica [20]

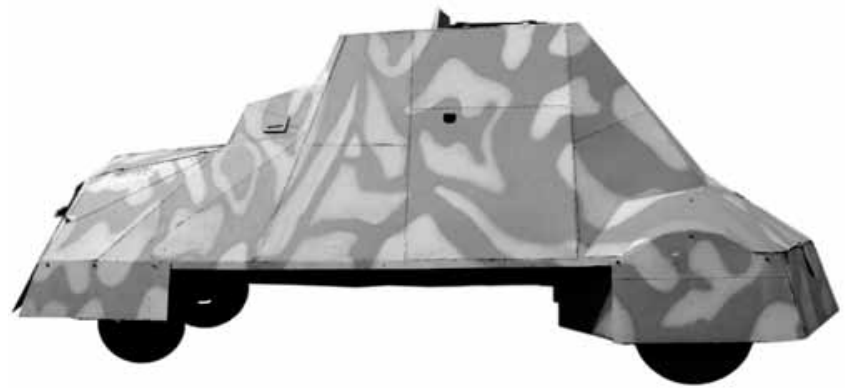

Rys. 5. Powstańczy wóz bojowy Kubuś

Fig. 5. Insurgent Kubuś fighting vehicle

W pistoletach Sten metodą spawania wykonywano magazynki, łączono muszkę trójkątną z komorą zamkową, kolbę rurową ze stopką i wspornikiem, a także gniazdo magazynka (rys. 3) [8].

Spoiny angielskie były gładkie, natomiast polskie grube, miejscami nierówne, więc po spawaniu można było broń odróżnić [7]. To nierówne i niedokładne spawanie mogło, szczególnie w przypadku magazynków, spowodować nieprzewidziane zacięcia, dlatego zaniechano ich produkcji [7]. Według inż. Czerniewskiego problem magazynków rozwiązał jesienią 1943 r., spawacz Marian Spychaj, zatrudniony w Zakładach w Suchedniowie [9]. Wykonał je z blachy obustronnie szlifowanej i lutował twardo bronzytem (spoiwo mosiężne) wzdłuż tworzącej [10]. Był wyjątkowo uzdolnionym mistrzem blacharskim i spawaczem. Wykonał pierwsze magazynki do polskiego modelu ręcznego karabinu maszynowego typu browning dla oddziałów majora Hubala. Prowadnice nabojów utwardzał za pomocą palnika acetylenowego [11].

Innym rodzajem broni spawanej, wzorowanym na Stenie, był KIS opracowany przez Polikarpa Rybickiego ps. Konar, Witolda Szafrańskiego ps. Igo i Stanisława Skorupkę ps. Smrek (rys. 4). Nazwa pistoletu pochodzi od pierwszych liter pseudonimów konstruktorów. Pistolet nie miał kolby, a lufa była pozbawiona osłony [2]. Części pistoletu spawano w Wąchocku 
lub w Szkole Wetalowej Zakładów Starachowickich. Znaczną trudność stwarzało zaopatrzenie w tlen i acetylen do spawania. Butle z tlenem dostarczano

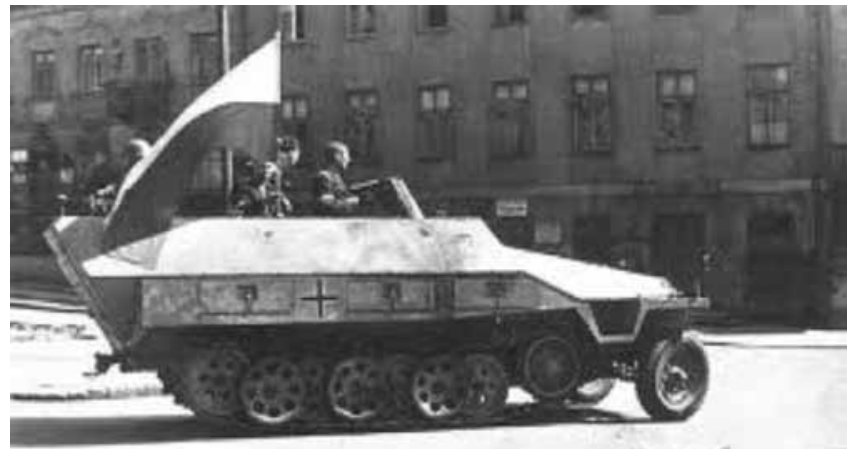

Rys. 6. Wóz bojowy Szary Wilk [19]

Fig. 6. Szary Wilk carrier [19]

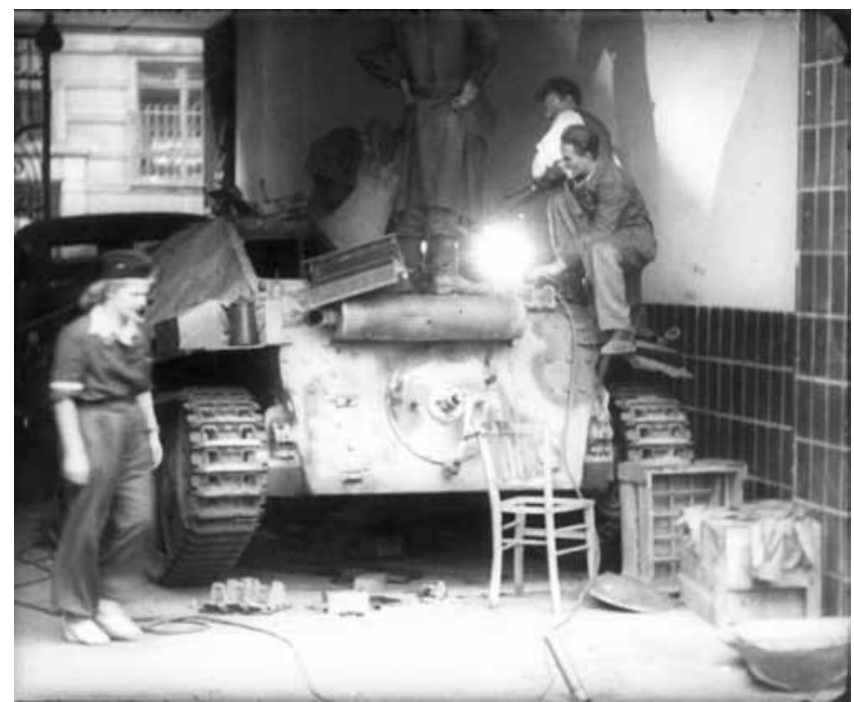

Rys. 7. Działo samobieżne Chwat w bramie Poczty Głównej [arch. J. Lassocińskiego]

Fig. 7. Chwat self-propelled gun in the Main Post Office gate [J. Lassociński archives]

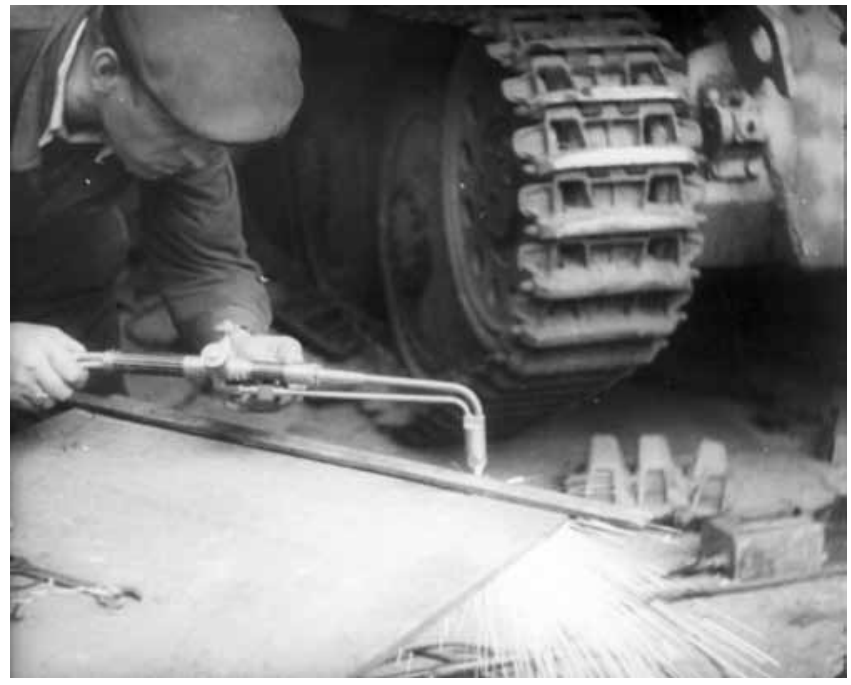

Rys. 8. Spawanie działa samobieżnego Chwat [arch. J. Lassociński] Fig. 8. Welding of Chwat self-propelled gun [J. Lassocińskiego archives] okresowo, trudniej było zdobyć butle z acetylenem. Ponieważ karbid był wówczas dostępny, zaczęto poszukiwać wytwornicy acetylenu. Pierwszą, niewielką, uzyskano od właściciela małego warsztatu, drugą zdobyto podczas akcji przechwycenia sprzętu od ekipy naprawiającej słup wysokiego napięcia. Zdobyto również komplet nowych palników [12]. Do remontu broni stosowano lutowanie twarde mosiądzem [12] oraz spawanie acetylenowe [13].

Znaczną ilość broni wyprodukowano w Warszawie. Na użytek Armii Krajowej w kilku wytwórniach, do lipca 1944 r., wykonano 650 Stenów i ok. 2000 pistoletów Błyskawica [13], a dla Armii Ludowej ok. 100 Stenów [14]. W artykule nie omówiono konstrukcji Błyskawic, podobnie jak granatów „Sidolówka”, ponieważ nie były spawane.

\section{Pojazdy bojowe}

W Warszawie po wybuchu powstania, ok. $15 \mathrm{VIII}$ 1944 r., rozpoczęto budowę wozu pancernego Kubuś (rys. 5).

Prace odbywały się w garażu na rogu Tamki i ul. Topiel. Elektrownia Warszawska przekazała na ten cel samochód ciężarowy Chevrolet, blachy i kątowniki, sprzęt spawalniczy do spawania elektrycznego i acetylenowego oraz elektrody. Do prac też oddelegowano rutynowanego spawacza Antoniego Nowakowskiego (Gryf) [15].

Arkusze blachy odpowiednio przycięte przyspawano do karoserii Chevroleta i szkieletu nadwozia. Stosowano wyłącznie spawanie elektryczne, gdyż tlen i acetylen oszczędzano do cięcia. Obawiano się, że w przypadku uszkodzenia elektrowni warsztat będzie musiał korzystać ze spawania gazowego, a wtedy brakowało gazów spawalniczych.

Za pomocą spawania przerobiono również zdobyczny transporter typu Viking [2], który nazwano na cześć poległego dowódcy Szarym Wilkiem (rys. 6). Konstrukcja chroniła załogę od góry zamontowanym stropem, a także, podobnie jak w Kubusiu, przednie koła wozu osłonięto blachami pancernymi. Dalsza przeróbka polegała na podwyższeniu czołowej osłony pancernej i przedpiersia strzeleckiego.

2 sierpnia 1944 r. powstańcy warszawscy zdobyli działo samobieżne Hatzer. Maszyna była w znacznym stopniu nadpalona i przez pewien czas była wbudowana w barykadę na Szpitalnej. Po kilku dniach pojazd odholowano do bramy Poczty Głównej i wyremontowano, wykorzystując narzędzia ze zdobytego na terenie Poczty Głównej warsztatu naprawy samochodów pocztowych oraz urządzeń do spawania acetylenowego i elektrycznego, sprowadzonych z elektrowni na Powiślu [2, 20]. Działo o nazwie „Chwat” stało niestety bezużytecznie w bramie Poczty Głównej, ponieważ skierowanie pojazdu do walki wymagałoby wcześniejszego rozebrania kilku barykad (rys. 7,8 ). 


\section{Podsumowanie}

Ruch oporu to nie tylko wytwarzanie broni, ale również dywersja w zakładach niemieckich. Wadliwe spoiny wykonano przykładowo w Hucie Bankowa i Hucie Zgoda przy produkcji kadłubów czołgów, kadłubów torped, w Zakładach Zieleniewskiego przy produkcji pływaków, czy w Ursusie przy produkcji podwozi czołgów [17].

Jak widać technologia spawalnicza pomagała w walce $z$ okupantem.

\section{Literatura}

[1] Łukocz J.: Powstańcze wytwórnie granatów, Zeszyty Historyczne z. 70. Wyd. Instytutu Literackiego, Paryż, 1984 s. 86-94.

[2] Satora K.: Produkcja uzbrojenia w polskim ruchu oporu 1939-1944. Wyd. MON, Warszawa, 1985.

[3] Maliszewski W.: Granaty i armatki. Przegląd Techniczny, nr 13/1965.

[4] Satora K: Granatnik z Powstania Warszawskiego 1944. Muzeum Wojskowe T. 1. Wyd. MON, Warszawa, 1959.

[5] Blimel H.: Technicy z Szarych Szeregów. Przegląd Techniczny, $\mathrm{nr}$ 8/1966.

[6] Mazur M.: Szumiały nam świętokrzyskie jodły (bez miejsca i roku wydania).

[7] Jankowski S.: Steny z ulicy Mogilskiej. Wyd. Literackie, Kraków, 1977.

[8] Kochański S.: Pistolet maszynowy Sten. Typy broni i uzbrojenia. Wyd. MON, Warszawa, 1986.

[9] Czerniewski K.: Jeszcze o produkcji polskich Stenów. Przegląd Techniczny, nr 5/1965

[10] Czerniewski K.: Konspiracyjna produkcja pistoletów maszynowych w Suchedniowie. Wojskowy Przegląd Historyczny, nr 1/1966, s.144-174.
[11] Czerniewski K.: Współpraca tajnych warsztatów. WTK, nr 7/1974.

[12] Bronikowski A.: Broń leśnych ludzi. Przegląd Techniczny $\mathrm{nr} 22 / 1965$

[13] www.powstanie-warszawskie_1944.pl?uzbrojenie_AK.htm, 2011.

[14] Strzembosz T.: Akcje zbrojne podziemnej Warszawy 1939-1944. PIW, Warszawa, 1983.

[15] Nowakowski A.: Światło dla Warszawy - wspomnienia. Książka i Wiedza, Warszawa, 1973.

[16] Satora K.: Kubuś z Powiśla. Przegląd Techniczny, nr 38/1966.

[17] Matusek P.: Ruch oporu w przemyśle wojennym okupanta. Wyd. MON, Warszawa, 1983.

[18] http://www.naukowy.pl/encyklopedia/Granat_r\%C4\%99czny_ET-40_Filipinka, 2011.

[19] http://www.powstanie-warszawskie-1944.pl/uzbrojenie AK.htm, 2011.

[20] http://pl.wikipedia.org/wiki/Pistolet_maszynowy_Kis, 2011.

Dolnośląska Sekcja Spawalnicza SIMP, Zakład Spawalnictwa Instytutu Technologii Maszyn i Automatyzacji Wydział Mechaniczny Politechniki Wrocławskiej, EUROMAT Sp. z o.o., Wrocław

zapraszają do udziału w

\section{Międzynarodowej Konferencji Naukowo-Technicznej "NAPAWANIE - POSTĘP i ZASTOSOWANIA" WROCKAW 2011}

19-21 września 2011 r.

aula A1, bud. B4 PWr, ul. Łukasiewicza 5

\section{Zainteresowanych prosimy o kontakt:}

dr hab. inż. Andrzej Ambroziak prof. nadzw. PWr - Przewodniczący Komitetu Naukowego tel.: 7132021 48, e-mail: andrzej.ambroziak@pwr.wroc.pl

dr inż. Hubert Drzeniek - Przewodniczący Komitetu Naukowego tel./fax: 7134845 36, e-mail: h.drzeniek@euromat.pl

dr inż. Piotr Białucki - Sekretarz Komitetu Naukowego tel.: 7132042 71, e-mail: piotr.bialucki@pwr.wroc.pl

dr inż. Ryszard Kaczmarek - Przewodniczący Komitetu Organizacyjnego

tel./fax: 7134845 36, e-mail: r.kaczmarek@euromat.pl

mgr inż. Anna Woźna - Sekretarz Komitetu Organizacyjnego

tel.: 7172020 74, e-mail: anna.wozna@pwr.wroc.pl

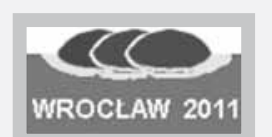

Korespondencję prosimy kierować pod adres: Komitet Organizacyjny 1. Międzynarodowej Konferencji Naukowo-Technicznej NAPAWANIE - POSTĘP I ZASTOSOWANIA Politechnika Wrocławska, Zakład Spawalnictwa ITMiA Wybrzeże Wyspiańskiego 27, 50-370 Wrocław 